1933

\title{
Complications of spinal anesthesia
}

Roy C. Rehder

University of Nebraska Medical Center

This manuscript is historical in nature and may not reflect current medical research and practice. Search PubMed for current research.

Follow this and additional works at: https://digitalcommons.unmc.edu/mdtheses

\section{Recommended Citation}

Rehder, Roy C., "Complications of spinal anesthesia" (1933). MD Theses. 284.

https://digitalcommons.unmc.edu/mdtheses/284

This Thesis is brought to you for free and open access by the Special Collections at DigitalCommons@UNMC. It has been accepted for inclusion in MD Theses by an authorized administrator of DigitalCommons@UNMC. For more information, please contact digitalcommons@unmc.edu. 
THF COMPLICATIONS

OF

SPINAL ANESTHESIA

SENIOF THESIS

UNIVFFSITY OF NEBRASRA COLLEGE OF MEDICINE

APRIL 21, 1933.

BOY 0 . FEHDER 


\section{TABLE OF CONTENTS}

\begin{tabular}{lr} 
Introduction & 1 \\
History & 2 \\
Fall in Blood Pressure & 4 \\
Respiratory Paralysis & 7 \\
Pulmonary Complications & 10 \\
Nausea and Vomitine & 12 \\
Headache & 18 \\
Meningitis & 16 \\
Neuritis and Palsies & 17 \\
Psychio Disturbances & 19 \\
Conclusion & 19 \\
\multicolumn{2}{c}{ TABLE OF CONTENTS } \\
FOA REPORTS
\end{tabular}

Case:

1. Respiratory Failure and Fall in Blood Pressure $2 I$

2. Ocular Complicatione 22

3. Heareche 22

4. Headache 23

5. Paralysis of Lower

6. Vesical and Anel Sphincter Involvement 55 
THE COMPLICATIONS OF SPIIAL ANTSTHESTA.

\section{INTRODUCTION}

Spinal aneothesia is that special form of anesthesia induced by the injection into the subarachnoid space of an anesthetizing solution. This results in spinal block due to local absorption of the solution with effects on the spinal cord and spinal nerve roots within the dura. Thie form of anesthesia is eesentialiy a root block of the epinal nerves, both sensory and motor. There is a further effect upon the vasomotor nerves which has claimed the attention of surgeone using this form of anesthesia. (Poe, 1932) Maintenance of consciousness is one of its characteristic features. (Labat, 1928)

To begin with we find some disgension over the rames applied to thie form of anesthesia. Some terms used are spinal anesthesia, spinal analgesia, lumbar anesthesia ana Eubarachnoid blcok, Caee (1828) states that the wora lurabar is strictly correct and prefers its use. The first name is the one noet commonly used although some of the others mabe more sultable and acientifically oorrect. Most authore are fairly well agreed upon the possible complications and their treatment, but somewhat at variance as to their etiology. However, through experimentation the profesion has ben considerably enlightened, more eo in the past eight to ten yeare than in the three decades precyeding. 


\section{COMPLIOATIONS OF SPINAL ANESTHESIA}

With regard to the inoidenoe of comolications the various authors show a differenoe of opinion on this matter. In 1200 cases, Case (2928) found three with complicatione. Faweett (1931) and Levine (1930) steted the com plications are rare, a etetement which probably represents the facts and findings of most of the surgeons today.

\section{HISTOFY}

Spinal anesthesia is not a new procedure but for the past three decade has had a Iimited vogue in this country and Europe. It failed to attain the popularity ite advocotes had hoped it might, and so very little was done with it. Just prior to the World War there wae a reawakening of interest but it again waned and fell to a low ebb. About ten years ago it wes employed by eurgeons in variove sections of the country and it became a topic for soientific discuseion. Articles by the score appeared in the medical and surgical journale. Soon the subject occupied a conspicuous position in the minde of hundreds of surgeons in this and other countries. (Welton, 1988)

Spinal anesthesia has been gradually improved through the years by the efforts of various men. J.Leonard cornine (1885) of New York City is creaited with being the first to launch the subject. He performed the first lumbar punoture on a dog. In 1885 he produced the firet aneethesia by the intraspinal method. Bier (18eg) reported six.cases.He carried 
COMPLTCATIONS OF SPINAL, ANFSTHESTA

on an experiment on himself and his aseiestant and described the ensatione. The method became popu-lar for a short. time in America and France whers Tuffier was responsible for bringing the procedure into prominenee. (Garside, 1931) From 1900 on spinal anesthesia was employed sporadically and its use was confined to elaerly people when Pitkin (1928) firet used it in 1912. These were the so-called bad risk cases.

After the World War there appeared occacionel articles on the olirical aepects of the eubject. Babcock (1025) and Bower, wagoner and Clark (1986) were come of the contributors. The stimulue for verious articles on the subject was given by Pitkin (1928) when he rublished hie article on "controllable spinal anesthesia" in which he diecuesed the ves of olutione lighter or heavier than epinal fluid. This also gave a etimulus for a wide spread ue clinically. Its use in head, neck and thoracio eurgery was discuesed by Koster (1928); Evane (IS28) delved into the technique and treatment of complications; Labat (1928) considered the importance of the Trendelenburg position. Other articles were publiehed by siee (1932); Severs and Tatere (1932); Cotui and Standard (1932); Eabcook (1828); Bower, Wagoner, Clark and Burne (1932), and many othere. 


\section{COMPLICATIONS OF SPINAL ANESTHESIA.}

\section{FALL IN ELOOD PEESSURE}

Fall in blood preseure in epinel ans thesia has been the topic of much discussion with authors on this subject, epecially aring the past ten years. It has always been in the mind of the surgeon fnd has given him great conoern. "The most dreaded of all corplications of epinal aneathesia" is Evang (19e8) opinion of it. It is fairly well agreed that there is a sight fall in blood preswure, between 10 and 20 mr. Hg., following injection in spinal aneethesie. This ehould cause little coneern, be compatible with safe anesthesia and ie uoualiy well born. (Aigner, 1826;Domeneon,183e) The latter author states that this hypotension is not aesociated with respiratory dieorders.

The blood preseure may fall so low, however, as to produce nausea, vomiting, palior of the ekin, thirst and air hunger, oold sweete, and ooliapse. The pressure hay fall to zero. The functions of the liver, kidneye and other orgene may be greatly diminished. The patient may become unoonscious with cescation of the heart beat. If the respirations are not allowed to ceese wa the heart beat is maintained, with proper treatment the blood preseure may be restored and the patient nons the rore becase of it. This type of fall has given the greatest concern and has been the object of experimental work through the years, more eapeoially in the past eight or ten yeara. 


\section{CONPLICATIONS OF SPINAJ ANFSTHESTA}

Several explanations have been offered for this fall in blood prescure. nönitz (1903) and lapp (1904) thought it due to abeorption of the grug into the circulation with a toxic action. That the drop in blood presour was due to direct action upon the nerve certers ws the contention of Heineke and Laeven (1906). Tuffier and Hallion thought it was due to action on the cord or nerve roots. (Crodineny and Eeker, P.o.) Schilf and Ziegner (1824) etated it was due to action upon the preganglionic fibers of the thoracio region. Swith and Porter (2915) advanced the theory of action on the eplanchnic nerves by the anesthetic solution to cause paralyeis and a conequent fall in blood preocure. stout (1920) agreed with this theory. Wialanski (1928) thought it aue to congestion of blood vesel in the akin. Experimental work in the year 1832 oroduced enlightening data. Bower, wagoner, Clark and Burns stated the falI in blood preseure was not due largely to eplanchnic dilatation. They thought that paralyeis of the irtercostal and phrenio nerves interdered with respiration caueing venoue staeie in the right heart and ite tributaries due to 108 s of the eucking action of the chest; therefore, fall in blood presoure wes the reeult of myocerdial weakneas. Severs and Matere found only a moderate alteretion in blood pressure with anesthesa to the tenth doreal eegment. In high spinal biock they found a progreseive lose of vasoular tone over the whole body and acute cardiac 
COMPLICATIONS OF SPINAL ANESTHESTA.

incompetenoe, both the result of oxygen deprivation as the evokjng action of the chest is interfered with through intercostal and phrenic nerve paraiyeje. Thio produced a profound fall in the preseure. " nomenect, tound that high epinel block caused a marked hypoteneion. Grodinsky and Baker (P.C.) performed an experiment in which they carried on artificial reepiration to prevent any poesible wyocardial weaknese through interference with respiration and found the fall in blood preseure despite the precatione. "Out of this maze of evidence one fact stands forth, the effect on the blood presoure is due to iooal action upon the nerve roote, cord or medulla, and not to absorption into the circulation.......the usual fall in blood pressure must have been due to reduction in peripheral resistance, Which means the anestheeia mut have effected the vasomotor system......the medullary center or the preganglionic eympathetic fibere."

If the idea thet the fall in blood preseure is due to the effect on the vasomotor system is accepted, it is eviaent that the anesthetio solution should be confined below the miathoracio region of the cord for anesthesia in that part of the body below the diaphragn. This is aue to the fact that the vacoonstrictor fibere energe from the first thorsoic to the third lumbar segments of the cord (staring, 1930), and the higher the anesthetio reaches in the thoracio 
COMPLICATIONS OF SPINAL ANESTHESIA.

region the more extensive the vacomotor paralysis and the greater the fall in blood pressure.

This foll is a gradual one when the effect ie produced on the fibere below the medulia, but abrupt when the solution reaches the meduliary centers. Ferguson and North (1932), Bower, Wagoner, Clark and Burne (193z), and Grodingky and Baker (P.C.) agree in their conclusione that about one-third of the blood preseure change ie due to dilatetion in the splanchnic area, abdominal wall and lower extremities; and two-thirde to vasodilatation in the head, neck, upper extremities, thorax and its contents. "Whether or not there is agreement upon the percentage influenoe of regione mentioned upon the blood preseure, it seme quite clear that there is a cumulative action with upward progreaeion and one met expect a Erester fall in blood pressure with higher anesthesia. "(Grodinsky and Baker, P,C.)

\section{RESPIRATORY PARALXSIS}

Another poseible complication of spinal anesthesia le that of respiratory paralysis. It may ocour immediately or follow very shortiy unon the ocmpletion of the operation when the patient is raied to the horizontal position after being in the Trendelenburg position during the operation. (Evane, 18a8; Poe, 193z) Severs and Waters (1932) state that resiratory paralysie is the ugual cause of immediate death from spinal anesthesia. 
COMPLICATIONS OF SPINAI, ANESTHESIA.

Various reasons have been assigned for the cause of respiratory paralysis. Jones (1832) attributes it to an overaoge of aneethetic solution in the blood and action then on the reppiretory center. He agrese with Poe (1932) that preoperative medication with narcotice or other adjuvant aruge may be a contributing factor. Buibar anemia is advanced as a cause by Evane (1928) and Roeder (1932). The latter author includee a central or peripheral origin or a clock of the motor nerves of thoracic respiration ae poesible ceuses. Ferguson and North (1836) speak of the dual control of reapiration, the intercostal nerves and the phrenio nerves. If the former are paralyzed the letter carry on with an adequats diaphragmatio type of bresthing. When the latter of the center iteelf are paralyzed, compete cossation of reepiration ocours. Grodineky and Baker (E.O.) agres thet definite changes in repiration may result as outlined above by the injeotion of volumes of the anesthetio solution sufficient to reach the various levels. The majority of authore eem to favor the paralyide action of anesthetic colution unon the thoracic end cervical nerve roots and the respiratory center as the etiological factor jn the production of reepiratory paralyois.

In the production of this complication there are three mechenieme or combinatione of them whioh may be involved: In the first ingtance there may be airect action on the 


\section{COMPLICATIONS OF SPINAL ANESTHESIA.}

respiratory center in the medulia by aiffusion of the drug to the fourth ventricls. This type may be excluded from eerious consideration as exoessively high conoentratione of the anesthetio solution are required to bring about this effect. Another mechanism is that of insuffioient nutrient flow of blood through the reepiratory centers in the medulla econdary to cardio-vascular depreseion which is, in oome degree, attenatant on intradursl block involvtrg the upper part of the abdomen and the thorax. Seevers and Waters (1932) attribute the majority of cases of respiratory tailure to this mechenism. A third mechaniem concerns the ascending block of the intercostal and cervioal nerves. The above authors think this type is unquestionsble preventable, and secondery to inexperienoe in the technical apecte of the procedure; or to unsuccesstul attempts to produce e sejective seneory nerve block of the upper thoraoic and neck regione. Grodinsky and Baker (P.O.) feel that the greateet safety in this type of anesthesis consists in confining the eolution below the midtoracic region of the cord becave of the effect upon the reepiratory nerves and medullary centers. Evans (1968) states "true respiratory failure if due to high aresthesia and $j+$ will vary $i$ th the height and concentration of the anesthetio."

If the aresthetio golution be confined to the lower or lumbar regione of the epinal canal by the Trendelenburg 


\section{CONPLICATIONS OF SPINAL ANESTHESIA.}

position or through other means, the danger of this complication ia practically nil. When upward difusion takes piace the thoracic nerve roots axe affected end conequenty the action of the intercostal muecles ie loet. This throws the burden of reepiration upon the diaphragm. If diffusion proceeds to the cervical region, becaues of involvment of the fifth, fourth and thira cervical nerve roote, thie unaided diaphragmatic breathing may cease such that tidal air cannot be moved. True respiratory paralyeis has begun and the condition may be overlooked until far advaneed. The fatient ma still be able to move the lips and tongue but be unable to talk. Cyanosis and unconeciousness may develop and the hest stop beating unlese artificial resplration is begun. "This is the important corplication of high anesthesia and may prove fatal unlese the operator underetande what is happening and is prepered to meet it." (Evane, 1928)

\section{PULMONARY COMPLICATIONS}

Pulmonary comlications have not received attention in the eame degree as other comlicatione. Sise (1932) gives some idea of the incidence. He saye that Elwyn found an inoidence as low as $0.75 \%$ in operations on the extremities; while Pasteur found as high se $13.4 \%$ in operatione on the stomach.

In the pulmonery comications the dominant factor is evidentiy in the operation iteelf end may well have a 


\section{COMPLICATIONS OE SPLAL ANHSTHESIA.}

relationehip to the changes produced in the lunge by operation. They are most conspicuous after upoer abdominal operations. The changes, briefly, are es follows: The diaphragm is elevated; the circumference of the chest is increaeed; the tidal excureions are reduced to one-half their preoperative amounte and the maximum exoursions to one-third. Before operation the tidal excursions ars in the lower onethira of maximu and after operstion in the voper one-third. X-rays in moet cases show increased trunk ehedows, hazinese and motting. Picture teker during full inepiration after operation have moh the eame eppeerance a those taken during expiration before operation. Often there are temporary clinical gigne ge tubular brething and rales. (S1ee, 1932)

Erown (1831) found the greatest number of cares of post-operative pulmonary atelectasis in ceses in which spinal anestheie had been employed. He found few etatiatica available but hie impresaion is definitely that the incidence of guznonary ateleotasie is gregter following spinal anes thesia than following ary form of inhalation or regional anesthesia. This impreesion holds regerdjese of the type of operation unäertaken.

Feasons that spinal anesthesio might predispose to this complicetion are: (1) There ie decreae in the depth and force of the respiratory movements during the operation and 
CONPLIOATIONS OF SPTNAL ANESTHESTA.

for a considerable pexiod afterward which retards the riddance of foreign matter or secretion from the tracheobronchial tree. (2) The viecosity of the secretions of the tracheobronchial tree appears to be increased; the material ie more tenacious following spinal anesthesia. (3) The potient tende to remain relatively quiet for a number of hours following operatione with spinal sneethesia. The subsequent development of stelectasis appeare reasonable. NAUSEA AND VOMITING

Evane (1928) gtates "nausea and vomiting ocour oniy where there have been errors or omiseione in the procedure.....there is ro severe post-operative naugea and vomiting atter spinal anesthesia alone." When these symtoms oocur during a spinal anesthesia there may be several different causes and the majority of them may be eliminated. Durire the first fiftesn minutes there may be nausea and vomiting from cerebral anemia or sudden moving of the patient. It may be slight naveea or mey go on to severe vomiting. In another type the pationt may develop certain mental impreasione which may be termed a peychic nauea. These upsete commony follow upon a lack of preoperative gedation and poor peychology on the surgeon's part. The patient's mind mey be overective with terrifying thoughts racing through it and, in conjunction, the surgeon way aek 
CONPLICATIONS OF SPINAL ANESTHESTA.

thoughtlese questions, all of which results in nauses snd, possibly, vomiting. A11 mey be proceding well when the petient suddenly becones extremely nauseated, vomits and extrudes the visoera. through the abdominal inoieion. With sufficient preoperstive sedotion and an entertaining and cooperative anesthetiat this complication nay be eimin$a t e d$.

In a third type of vomiting the torm reflex may be apolied. In euch a situstion, to an already existing cerebral anemis is added a disfunotion which may be sufficient to start reflex vomiting. With thoraco-abdomins 1 paralysis cauking axceseive action of the diaphragm in breathing, a avder change in cooition of the patient, packing ageinet the stomeh and manipulation of the stonach and duodenum, all interfere with the normal function of the stomach and may lead to this type of vomiting.

As an acompaniment of the epinal punoture headache, post-operative naues and vomiting may develop. It may be one of the eymptoms, too, of meningeal irritation or infeotion. When the cther conditions imorove this symptom disappears. (Evans, 1928)

\section{HEADACHE}

The complication of headache is one that has produced a great deal of comment by the authors in their various 


\section{COMPLICATICNS OF SPINAL ANESTHFSIA}

articles. It has been termed the noot frequent, troublesome and annoying complication of opinal aneethesis. (Koster, 1928; Evans, 1928; Koster and Weintrob, 1930) The incidence hae been etated as low ae ten per cent and as high as forty per cent. (Rorgonova-Mulier, 1930; Roster and Weintrob, 1930)

The headache is usually either parietal or ocoinital in Iocation; difuee or locallized and ascociated with some degre of etiffnese of the neck muscles. In severe forme it may be lancinating or pulsatile pain accomanied by pajns over the epine, vomiting and ireomia. The majority of patients affictea begin to complain, as a rule, within twenty-four hour after the operation. The intensity of the headaches varieg and in most inetance they are of such mild degree that they dieapper within twenty-four to seventy-two houre. The severer forme may persist as long as severel weeks.

There have been various theories advanced as to the etiology of the headaches which follow spinal anesthesia. These theories are the toxio, olroulatory, mixed, meningeal irritstion and hyaraulio. Chief among these, however, are the circulatory, meningeal irritation and hydraulic. The supporter of the oirculatory theory include euch authore as Angelesoo, Buzianu and Ceramzuleeco (193a). In this type the vascular mechaniem is, as yet, imperfectly determired. Changes in the normal tonus of the blood 


\section{COMPLICATIONS OF SPINAL ANESTHESIA}

vesees thay produce disturbances of blood ciroulation is the brain. Vaoomotor pareic may cave dilatation of the capilaries of the dura mater and comprese the eneory nerve filamente to produce headache. In addition to the firet theory the above-mentioned authore with Kennedy (1932); Caee (193z); De Courcy (1928) and Fvane (1938) support the econd theory. Meningeal irritation ie produced by trouma becave of repeated punctures or through the lise of too large needles. The eupporters of the thira theory, Andereon (1931); Cace (1928); De Couroy (1928); Pitkin (1968) and Kooter and Weintrob (1930), poetulate an increase or decrease in the amount of spinel fluid following the epinal puncture. In the event of an increase there are the signs and symotome of a meningitis or meningismus; etiffnes of neck, photophobia, headache and a poecible poram Iyeis of the external rectus muscles of the eye. With a decrease in the amount of spinal fluid the brain may sag againgt the bony frame work of the skull resulting in irritation and a consequent headache. Pressure upon the basilar venous plexus may result in increased venous tension and result in headache.

If the headache is of the type that resulte from an increase in the amount of the splnal fluld, no relief is obtaned by lowering the head and ohouldere. If of the type in which there is deorease, no druge give relief but lowering the head and shoulders giver relief. (Evane, 1928) 


\section{COMPLICATIONS OF SPIMAL ANESTHEIA.}

\section{MENINGITIS}

Meningitis, as a complication of epinal anesthesia, is one dependant upon the ekill and commend of technique of the operator, making its appearsno ir that order. The cages reported are usualiy of a mila type. (Evane, 18z8; Hertz, 18zE) Meringismu, a non-infective meringitis, is eseentially sn irritation of the meninges. Trauma to the dura, punctur of a dural vessel, injection of toxic doses of the arug or of foreign material may result in a congestion of the meninges with a resultant exudation. Within tweive to twenty-four hours the meningisme is usually ushered in with meningeal symptoms such as headache, diziness, stiffness of neck and photophobia. These usually persist for two to three days and then subside spontaneouely. No relief is obtained by the adminietration of coal tar derivatives or codein. (Fivans, 19:8, Koster and weintrob, 1930)

The true purulent variety of meningitis is a rarity. The appearance of this type of meningitis depende again on the technique and skill of the operator, but it is the geme risk that eccompenieg any eurgical procedure. Within the firet twenty-four to forty-eight hours the symptome usully appear. Headache and restlessnese are usualiy attended by stiff neck, increased temperature and ocvlar aborrations. Then the characterietic signe of purulent meningitis 


\section{COMPLIOATIONS OF SPINAL ANFSTHESTA}

become evident. The course jo uqualiy ten to fifteen dayo, aftex which it tende to olear up spontanesouly with no reaidua1. (Andereon, 1931; Koster and Weintrob, 1930; Evane, 1928) NEUPITIS AND PALSIFS

The after-effects of spinal anesthesia in regard to the poesibility of a comolicating neuritis and paley are evidently quite rere and fortunately, if they occur, only transisnt in nature and of ehort duration. (Koster and Weintrob, 1930; De Courcy, T928; Fvane, 1928; Anderson, 1931) There are two types generally recognized, those occuring becauge of irritation or trauma at the site of punoture and those further removed, the ocular paleiee.

In the firet type the notor or seneory deturbenoes may be due to trauma to the nerve roots, epinal or cauda equina; through recested attempte to puncture or through the use of too laree nedies. (De Courcy, 1828; Babcock, 1828) The symo torn wey be eharp, lanoinating paine along the course of the nerve, mocie epaem, enetheeia or paresthesias of the lower extremities, or irritation to the ansl or vesical ephincters. If the damage is evere the resulting disability may be quite permanent. Interruption in the continuity of the nerve roots reeulte in permanent damage. Puncture of the cord lisualiy causes neither pain or after-effecte. (Fvane, 19z8) 


\section{COMPLICATIONS OF SPINAL ANESTHESIA.}

The later paleies are confined to the extra-ooular musoles and, of these, the external rectus, which is eupplied by the abducens or sixth cranial nerve, js the one commonly affected. The condition may be unilateral, bilateral and as frequently in either eye. (Xoster and weintrob, 1930, Fawott,1931; Evens, 1928; fnderson, 1931) The more important theories concerning the particular involvment of abducens nerve are two in number. The first theory aseigne it to a special susceptibility to the drug. The second refers to the longer passge of the abducens nerve through the spinal fluid, in which it ouffers more from exposure to the drug or spinal fluid contaminations than do the other cranjal nerves.

The symptoms are usually a preliminary photophobia, poseibly headache and dizziness, and a supervening diplopia which is uevally homonymous. Outward motion is limited and there may be a convergent equint. After about ten days the condition ueually shows elgns of beginning cure, and generaly clears up sponteneously in a month or two. (koster and Weintrob,1930; Evans, 1928; Fewoett,1931; Bufi11,1920)

Backache occure in a sell percentage of cases. Koster and Weintrob (1930) found a two per cent incidenoe. Trauma to the soft parts or etrains or bruises, at the time when the patient is unable to react to a cramped or uncomfortable 
CONPLICATIONS OF SPINAI ANTSTHESIA

poeition may be the cavee. The durations is short, sometimes a week. Relief may be obtained by placing a pilow under the baok.

\section{PSYCHIC DISTIEBANCES}

Very little coneideration is given to peychic disturbances in the literature. This leade to the conclusion that avch a complication 1o rare. Koter and Weintrob (1830) report a case by Izquirdo which developed into a hypochondriac. From the same source there is a report of a case of insanity. Daseen (1930) had a case of grave neuro-peychosis after eleven days. It was cheracterized by mental confusjon. The patient was inactive for four monthe. Dasen considered a toxic influence was the most probable cause of the disturbance.

\section{CONCLUSION}

Although spinel anesthesia has been enoloyed for over three decades, it has been only within the pact few yeare that much has been accomplished with it. The complications which followed in ito wake mede many urgeone catiou and fearful of ite use. Extreme fall in blood preacure and respiratory paralysis are rarely encountered, but when they do ocour may readily reaul fataliy. They are to be feared and avoided if poseible. The other complicatione are troublesome and annoyine, but oeldom result ir death, and may be avoided 
COMPLICATIONS OT SPINAL ANESTHESIA.

with proper use of this type of aneethetic, and by using proper technique.

With the knowledge at hand from experimental work and experience of the years to guide, the surgeon is now better informed and prepared to meet the complicetions should the ocoasion ariee. It may be seen that spinal anesthesia has its limitations, and should be used only in that part of the body below the mid-thoracic region of the spinaz cord. If such procedure be followed there need be lit tle conoern about complicstions following the use of spinal anesthesia. It ehould then follow that much of the fear of the patient will be dispellea. Rnowing that it is not more dangerous than any other from of ane thesia used in ite proper place, he will have more confidence in its use when euch is indicated. 


\section{CASE REPOFTS}

Case I. Respiratory failure and fall in blood pressure.

The following case illustrates the dengers of high aneethesia. Mrs. s., age 70. Interposition operation for cystocele and uterine prolapee. Spinal anesthesia by means of $300 \mathrm{mg}$. neocaine diecolved in $1 \mathrm{c} .0$. of spinal fluid, and injected into the firet lumbar interspace. The patient was i umediately placed in the doreal lithotomy position with the head lowered. The blood preseure before injection was 160 systolic and 80 diastolic. Ten minutes after injection it had falien to 80 systolic and 50 diastolic, but the patient"s general condition was good. The reepirations were quite normal except for the fect that they were more diaphragmatic in character. Pin teste showed that cutaneous anesthesia had reached the first throacic gegment. Ten minutes later the blood preseure was about the same, 75/45, but the cutaneous aneethesia had reached to the first cervical eegment, and the respirations were elower and wore shallow. Five minutes after this the reepirations addenly ctoped. The patient became cyanotic and the blood pressure could not be recorded. The pulse was feeble and slow, and soon could not be gotten at all. The heart sounds could not be heera. Artificial respiration was jmmediately inetituted, Strychnine sulphate gr.1/30 and al pha-lobelin gr.1/20 were given hypodermically; adrenelin, lo.o., wae injected direct Iy into the heart. Several minutes later the heart counds could be rade out, end a feeble pulse could be felt. After about fiftes minutes of ertificial respiration the pationt took a few spontaneous breaths which gradually increased in rate and depth until her condition was normal again.

A carefuz study of this case shows the typical progreseive effects upon the respiratory mechenism sen in the laboratory experimente. (Grodineky and Baker, P.C.) Firet there is a change to abdominal breathing to compensate for $10 \mathrm{~s}$ of the intercostals; then interference with the abdominal breathing by paralyeis of the orvical segments (phrenioe), and even possible effect upon the medullary centers (though thie would be relatively unimportant eince all the peripheral reepiratory nerves were alreadr affected). It is to be noted that there was an early arop in blood prescure (50\%) but that this was comptible with good respiration (though modified), and good general condition, showing the independenoe of changes in blood pressure and repiration. Furthermoxe, the blood pressure remained about the same until the respirations ceased entirely when it became imperceptible due to the anoxemia of the medulla, or possibiy to airect 
action of novocaine upon the vasoconetrictor ae weli as the respiratory centers. Until that time, however, the blood preseure had reached ite maximum fall due to peripheral vasodilatetion, and this correlated well with the level of cutaneous aneothesia, to and above the firet thoracio segment. That the had was alresdy down when the respiratory dificulties began, gives further evidence thet the latter wa not due to anemia of the wedulla, reaulting from fallen blood pressure. It is interesting to rote that, all though there was some fixation of novocaine arly, this we only pertial, and the effect continued to epread upward for twenty to twenty-five minutee after injection. The recovery of this patient must be ascribed to the artificial repiration inatituted, since the esential cause of the reaction was respiratory failure, and restoration of breathing was all important for recovery. However, the use of etimulante may heve had some additional favorable effect. Adrenalin may have stimulated the waning circulation particularly. (Grodinsky and Baker, P.C.)

\section{$* * * * * * *$}

Case II. Coular Complications.

Bilateral paralysie of the external recti (sixth pair). This patient came under observation in July of 1926, with a history of having been opearted upon under spinal anesthesia a month and a half previously. The diplopia eupervened a fortnight after the operation, following seriee of genersi dieturbances and eevere headache. During the pest month, he had undergone various treatments without any result and was now referred to the author by hie farily ohysician. Examination ehowed a well marked, all though not absolute, paralysis of both external recti muscles; vision was normal and the ocular fundue was normal. As the only treatment he was given potaseium iodide and galvanic and faradic currents, with the reault that after three monthe of treatment, he was completely cured. (Bufili, 1930)

Cese III. Headache.

The patient was a woman 28 years of age, who was curetted on July iet for placental retention. She was given epinal aneethesia with eycaine without removal of the cerebrospinal fluid. Her temperature immedately 
descended but on the next evening she began to complain of headache in the neck and frontal regions. This headache was increased in severity when she sat up, and was practically continuous without any eharp paroxysms durine the day or night. It was accompanied by vomiting. She could not elesp.

On the evening of July $3 \mathrm{rd}$ she still complained of headache and in addition had marked stiffness of the neck with photophobia but without Kernig's sign. A lumbar puncture was made and a few drope of clear fluid were obtained. The fluid followed only when she coughed or talked. There was evident hypotension but ehe seered relieved and passed a good night.

The headache and vomiting reappeared on July 4 th. She was much better on July 6 th and was able to sleep. However, on the 7th the headache returned and was almost continuous, al though it did not prevent her from sleping.

The headeche returned about $10 \mathrm{~A} . \mathrm{M}$ on the morning of the 8th with the same characteristics. She had a sensation of general fatigue and the neurologio examination showed sight stiffness of the neck, active tendinous reflexes, and photophobia but no ocular paralyeis. Another Iumbar puncture was made but only $l$ or $a$ arops of a clear fluid were obtained. She wa given a euboutaneous injection of $250 \mathrm{c.c}$. of salt eolution. She paeged a good night and the headache, stiffness of the neck and photophobia completely disappeared on the next day. (Wideroe and Dahlstrom, 192E)

Case IV. Headache.

The patient wes a man 28 years of $3 g e$, who was operated upon for a bilateral hallux valgus. The operation was performed on september 3rd. The cerebrospinal fluid escaped in a jet.

About 11 A.M. on the second day the patient had elight headache. The headache increaced in severity but he was able to reat. The headache returned on the morning of the 5 th and 10 c.c. of dietilied water was injected intravenously. The pain seemed to be increased when he sat up. On the morning of the 6th there was contracture of the neck but no Kernig's eign. His pulse was 70 and he had no fever. A lumbar puncture was made and only a few drops of normel fluid could be obtained. He was 
given theobromine but the headache became much woree in the evening.

The cocipiteI headeche we continuous and there were paroxyam without any apparent cause. There was no vomiting. Percuesion in the ocoipital region was painful. He had rather marked stiffness of the neck, but no paraIysis or nystagmue. There were no disorders of sensation. His pupils were elightly dilated but were equal end reacted to light. Another injectior of $30 \mathrm{c.c}$. of distilled water wae given intravenously withovt any immediate improvement. The theobromine wes continued and was so severe that morphine was necessary. He was much better on the sth and was able to eat. Chloral hydrate and bromidee were given in small doses for 48 houre. He became completely well on the 1zth. (Wideroe and Dahistrom,1922)

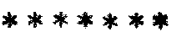

Case V. Paralysis of lower extremitiee.

The case concerns a woman who was operated for cystome. Lumoar anestheeia with 0.15 novocain and 5 drops of 1:1000 suprarenin solution. Further course was uneventiul, and the patient was discharged on sept. 10. End of December, pains manifeeted themselves in the Iumbar portion of the epine. January, paresthesia in both legs. Up to June, a gradual paralysis of the legs developed. June zoth, normal childbirth. Findinge a month later reveal a evere paresis of the flexor musoles of the lege with lose of position-muscle-and-touch-sense. A combination cord diecase of the pyramial tract and of the posterior tracts was agcumed. Whether it was genuine or whether it was a case of a diffuse inflammatory procese cannot be determined, as the autopsy findings were not complete.

The author coneidered pregnaney myelitio as becoming steadily less frequent. Some such cases have revealed themeelves as mitiple scleroeis. In thoe cases in the literature in which exact autopsy findings ars available, a circumecribed or diffuse inflammatory dieease was alwaye present, never a eystemio aisease. (MuIlet, 19al) 
25.

\section{COMPLICATIONS OF SPINAL ANESTHESIA.}

Case VI. Vesical and anal ephinoter involvment.

A man 59 years old coneulted the author for a rectal disorder which he believed was due to hypertrophy of the prostate. He had an inguinal hernia which was operated upon by means of spinal anepthesia. The operation was painless at first but later beceme painful and he had a violent reaction in 12 hours. His nervous condition was alich that on the third day he had a synoope lasting three houre. He was not able to urinate after the operation and catheterization was neceseary. He had no appetite for 8 days and when he began to eat he had diarrhea. His surgeon believed that he had a relaxation of the sphinoter and a contraction of the vesical ephincter.

The patient could not slep and he had pains and cramps in his legs. There was absolute los of sensation in the entire lumber and genital regione and the muscles of the cortex were hard on palpation. An attempt was made to re-establish the functions by means of electrioity at the end of the third week. A opeoialist found inertia of the anal and vesical spincters. There was no improvement after treatrent for one month. Since that time the patient has had constipation and has been obliged to use laxatives constantly. He has had urinary disorders conetantly and his urine has been oloudy and alkaline. A rectal examination showed a small prostate and the bladded appeared to be empty. There was lose of seneation of the ecrotum. The patella refiexes were slugeigh. Since the operation he has always had a eensetion of cold fet. He has no spontaneou desire to urinate and his rectum always has the sensation of being full.

Hence, there way be complications due to soinal anesthesia which may pereiet for years. (Bazy, 19er) 


\section{Bibliography}

Alegner, H., The collapse of the vasomotors in lumbar anesthesie and its prevention, Zentrab.f.Chir. 53:13671369, May 29, 1826.

Anderson, E.R., Complications, Journal-Lancet 51:403-407, July I, 1931 .

Angelesco, C., Buzoianu, G., and Caramzulesco, D., The pathogensis of headache after spinal anesthesie, Lyon chir. 29:521, sept.-Oct., 1932.

Arnheim, Ernest E. and Mage, Sigmund, Nupercaine, spinal anesthesia, Surg., Gynec.\&obst. 54:826-831, May 1932.

Baboock, Hyra E., Spinal anesthesia deaths: a survey, current researches in, Anesth.\&Analg. 11:184-188, JulyAugust 1932.

Babcock, Wayne w., Blood pressure in relation to spinal anesthesia, Anesth.\&Analg. 4:222-227, 1925.

Babcock, Wayne W., Experience of 24 years, Am.J.Surg. 5: 571-576, Dec. 1928.

Bazy, P., Note on the persistence of the effecte of spinaI anesthesia, Bul1. et mem.soc.nat.de chir. 53:243-245, Feb. 1827.

Bler, A., Versuche uber Cocainisirung des Fuckenmarkes, Deutsche Ztschr.f.chir. 51:361-369, 1899.

Bower, John 0. , Wagoner, G. and Clark, J.H., Clintcal and experimental investigation in spinal anesthesia, Anesth. \&Analg. 5:95-105, Apri1, 1926.

Bower, John O., Clark, J.H., Wagoner, Geo. and Burns, J.O., Spinal anesthesia, Surg., Gynec.\&Obst. 54:882-887, June, 1932.

Bromn, A.L., Postoperative pulmonary atelectasis: importance of different types of bronchial secretion and anesthesia, Arch. Sur. 22:976-982, June 1931.

Bufill, Perez, Ocular paralysis after spinal anesthesia, Arch.de oftal.hispano. 30:484-487, 1830.

Case, James T., Lumbar anesthesia, Am.J.Surg. 5:615-619, Dec. 1928.

Corning, J.L., Spinal anesthesia and local medication of the cord, New York M.J. 42:483, 1885. 
Cotui, F.W. and Standard, Samuel, Experimental studies on subarachnoid anesthesia, Surg.Gynec.\&obst. 55:290-296, Sept., 1832 .

Dassen, R., Mental confusion, grave headache and Parinaud"s syndrome following anesthesia: case, Semana Med. 38:13871388 , oct 11, 1930 .

Davis, L., Haven, H., Givens, J.H. and Fmmett, J., The effects of spinal anesthetios on the spinal cord and its memoranes, J.A.H.A. 97:1781-1785, Dec.12, 1831.

De Courcy, Joseph L., Nerer methods of controllable spinal anesthesia, Am.J.Surg. 5:620-623, Deo., 1928.

Dill, W. W., Statistioal and other observations on spinal anesthesia, Pennsylvania H.J. 35:244-346, Jan., 1932.

Domenech, Alsina, F., The circulatory and respiratory troubles provoked by spinal anesthesia and their treatment, compt.rend.Soc.de biol. 110:230-232, Wey 27, 1932.

Dönitz, A., "rokainisierung des Ruckenmarkes" unter VerWendung von Adrenalin, Munohen med. Wohnsohr. 50:1452-1454, 1903.

Evane, O.H., Possible complications; recognition end measures employed to prevent and combat them, Am.J.Surg. 5: 581-593, Deo., 1828.

Fa1k, H.O., Desthe from anesthesia, Am.J.Surg. 11:461-464, March, 1931.

Fawcett, K.R., Extramocular macle paralysis followling anesthesia, Minnesota Med. 14:648-649, July, 1931.

Ferguson, L.K. and North, J.P., Observations on experimental epinal aneethesia, Surg.,Gyneo,\&obst. 54:621-634, Apri1 1932.

Garside, I., Study of spinal analgesia based upon 357 personal cases, Ann.Surg: 84:898-814, Nov., 1931.

Gioseffe, M., Risks of spinal anesthesia, Reforma med. 38 : 866-969, oct. 9, 1922:ab.J.A.M.A. 79:2256, Dec. 30, 1922.

Grodinsky, Manvel and Baker, Chas...., Spinal anesthessa, a cinical and experimental study, 18-24, perconal comrunication.

Guibal, P., Dangers of spinal anesthesia, Presse med. 29: 
244, Harch 26, 1921; ab.J.A.M.A. 76:1373, May 14, 1921.

Helneke, H. and Laewen, A., Experimentelle Untersuchungen uber Lumbalanasthesie, Arch.f.Klin. Ohir. 81:373-411, 1906.

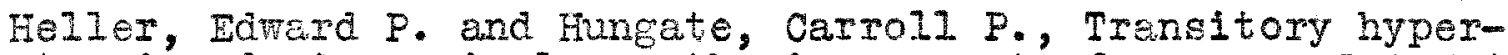
tension during spinal anesthesia; report of a case, J.A.M.A. $97: 1964$, Dec. 26, 1931.

Hertz, J., Accidents of spinel anesthesia, Paris med. 12: 214-218, harch 11, 1922; ab.J.A.M.A. 78:1348, Apri1 29, 1922.

Iason, A.H., Lederex, $\mathcal{H}_{\text {. }}$ and Steiner, $H_{0}$, Changes ir spinal fiuid following injection, Surg., Gynec.\&Obst. 51:76-80, July, 1930.

von Jaschke, R.T., Headaches after intraspinal anesthesia, KIin.Tohnschr. 4:65-66, Jan. 8, 1925; ab.J.A.H.A. 84:714, Feb. 28, 1925.

Jones, W.H., Sub-arechnoid block; general anelgesia; "spiral" anesthesia; respiratory paralysis; fallacies and methods, Brit.M.J. 2:488-493, Sept. 12, 1931.

Tennedy, A.J., Spinal anesthesia, olinical experiences in 430 cases, and a technique to eliminate post-operative headache, R.J.Australia 1:40-45, Jan. 9, 1932.

Klapp, Zur Spinalen Anasthesie, Deutsche med. Wohnschr. 30: $526,1904$.

Korgonova-Muller, F. and Orlovskji, J., The causes of headache after spinal anesthesia, Nov.chir.Arch. 22:102-114, 1830 .

Koster, H. and Weintrob, M., Complications, Am.J.Surg. 8: 1165-1179, June, 1930.

Koster, H. and Weintrob, M., Fatalities, Ar.J.Surg. 9:234242, Aug. 1930.

Koster, H., Spinal anesthesia in surgery of head, neck and thorax, Am.J.Surg. 5:554-569, Dec. 1928.

Labat, G., Elimination of dangers of spinal anesthesia, Am. J.Surg. 5:625, Dec. 1928.

Levine, J., Parelysis of extraocular muscle after anesthesia, Arch.Ophth. 4:516-520, oct. 1930 .

Molehee, J.I., Advantages and disadvantages, J.Tennessee M.A. 
Honthus, A., Ocular acoidents in spinal anesthesia, Medicine 4:273, Jan. 1923; ab.J.A.H.A. 80:1183, April 21, 1923.

Muller, A., Persistent severe spinal cord injuries after lumber anesthesia, Deutsche med.Wchnschr. 47:553-555, May 19, 1921.

di Pace, I., Retention of urine after intraspinal anesthesia, Policlinico (sez.chir.) 30:614-625, Dec. 1923; ab.J.A.M.A. $82: 425, F e b .2,1924$.

Pitkin, Geo. P., Spinocain, the controllable spinal anesthetic, The Brit.1.J. 3578:183-18\%, Aug. 3, 1928.

Pitkin, Geo. P., Controllable spinal anesthesia, Am.J.Surg. $5: 537$, Dec.1828.

Poe, James G., Modern general anesthesia, F.A. Davis Co., Phila. 213-215, 1932.

Rebay, H., Ocular complications of intraspinal anesthesia, Semana med. 1:718-722, March 26, 1925; ab.J.A.1.A. 84: 2031, June $27,1925$.

Roeder, C.A., Spinal anesthesia, J.A.M.A. 98:348, Jan. 23, 1932 .

Rygh, F.A. and Bessesen, D.H., Causes of deaths, Hinnesota Hed. 11:744-747, Nov. 1928 .

Satanovsky, P., Paralysis of rectus externus from intraspinal anesthesia, semane med. 1:809-817, April 22, 1926; a.b.J.A.H.A. 87:714, Aug. 14, 1926.

Schilf, $\mathbb{E}$. and Ziegner, H., Das Wesen der Blutdrucksenkung bel der Lumbalanasthesie, Arch.f.Klin.chir. 130:352-359, Hay, 1924.

Severs, H.H. and Taters, R.M., Circulatory changes during spinal anesthesia, Anesth.\&Anelg. 11:85-90, March-April, 1932.

Severs, M.H. and Weters, R.M., Respiratory and circulatory changes during spinal anesthesia, J.A.M.A. 99:961-968, Sept. 17, 1932.

Sise, I. F., Spinal anesthesia fetalities and their prevention, New England J.Med. 200:1071-1074, May 23, 1928.

Sise, L.F., Post-operative pulmonary complications, Anesth. \&Analg. 11:23-28, Jan.-Feb. 1932 .

Sise, I.F., Post-operative pulnonary complications; comparison of effect of spinal and ether anesthesia, s.clin. North America, 12:648-654, June 1932. 
Smith, G.G. and Porter, W.T. Spinel anesthesia in the cat, Am.J.Physiol. 38:108-12\%, 1815.

Sophoteroff, S., Complications of intraspinel anesthesia, Paris med. 1:48-5I, Jan. 12, 1824.

Soupalt, R. and Boulanger Pilet, $G_{0}$, Aseptio meningitia efter intraspinal anesthesia, Parie med. 13:239, sept. 29, 1923; ab.J.A.M.A. 81:2067, Dec. 15, 1923.

Starling, Emeet H., Human Physiology, Lea and Febiger, Philadelphia 5:785-805, 1930.

Stout, Richard B., Splnal Anesthesia, blood pressure control, Wis.H.J. 28:261-263, June 1928.

Strauss, M., Misheps with intraspinal anesthesia, Deutsche Ztachr.chir. 172:296-302, 1922; ab.J.A.M.A. 79:1462, 0ot. 21, 1822 .

Webber, I.M., Outward effects, Waine M.J. 22:186-188, sept. 1831.

Weigeldt, T., Injury of spinal cord from intraspinal anesthesic, Zentralbl.f.Cynak. 48:2432.2439, Nov. 1924 (111us.); ab.J.A.M.A. 83:1886, Dee. 6, 1924.

Welton, Thurston Scott, The past, present and future of spinal anesthesia, Am.J. Surg. 5:633-635, Dec. 1928.

Widerow, S. and Dehlstrom, S., Dangers of spinal anesthesia, Norsk mag.f.1aegeviausk $83: 450-453$, June 1922 .

Widerow, S. and Dahlstrom, S., The dangers of Iumbar anesthesia, Acta chir. Scandinev. Stockholm 55:27 32 , 1932.

Wislengki, Z., Spinal anesthesia complicetions, Polska gaz. lek. 8:657-662, sept. 8, 1929.

Ziegner, H., Vasomotor collapse in lumbar anesthesia and its prevention, Zentralbl.f.Chir. 53:1367-1369, May 29, 1926; ab.J.A.K.A. 87:71.4, Aug. 28, 1926. 